\title{
Number of Blood Cultures per 1,000 Patient Days at University-Affiliated Hospitals in Korea
}

\author{
Eui Chong Kim ${ }^{1}$, Jeong Hwan Shin'2, Sunjoo Kim ${ }^{3}$, Nam Yong Lee ${ }^{4}$, \\ Ji-Hyun $\mathrm{Cho}^{5}$, Sun Hoe $\mathrm{Koo}^{6}$, Nam Hee Ryoo, Sae Ick Joo ${ }^{1}$ \\ Departments of Laboratory Medicine, ${ }^{1}$ Seoul National University College of Medicine, Seoul, ${ }^{2}$ Inje University College of \\ Medicine, Busan, ${ }^{3}$ Gyeongsang National University School of Medicine, Jinju, ${ }^{4}$ Sungkyunkwan University School of \\ Medicine, Samsung Medical Center, Seoul, ${ }^{5}$ Wonkwang University Medical School, Iksan, ${ }^{6}$ Chungnam National University \\ College of Medicine, Daejeon, ${ }^{7}$ Keimyung University School of Medicine, Daegu, Korea
}

The authors calculated the number of blood cultures per 1,000 admitted patient days at seven university-affiliated hospitals in 2010 , which ranged from 65 to 129 (mean 110). The number of blood cultures per 1,000 patient days could possibly be a good pa- rameter for assessing the appropriateness of blood culture. (Korean J Clin Microbiol 2012;15:67-69)

Key Words: Blood culture, Cost, Sepsis, Quality control
Blood culture is the gold standard primary test to evaluate patients with sepsis. The need for use of blood culture is increasing, because the incidence of sepsis is rising [1,2]. Several guidelines for optimal blood culture have been proposed including timing and volume of blood collection, number of cultures obtained for each patient, and thoroughness of skin disinfection before collection [3,4]. However, the optimal number of blood cultures per year has not been well documented. Blood culture should be requested adequately, neither overused nor underused [5]. In the Cumitech 1C [4], released in 2005, the number of blood cultures per 1,000 patient days was recommended to be 103-188 in the USA. As the patient population, disease incidence, proportion of acute illnesses, and medical insurance systems in the USA are different from those in Korea, we cannot apply this data directly. The numbers suggested by this documentation need to be evaluated before to be applied to our country. The authors tried to calculate the blood culture numbers per 1,000 patient days, which to our knowledge has not previously been conducted in Korea. The absolute number of blood cultures performed per year could be difficult to compare among hospitals, because the proportion of acute illnesses, hospital size, and turnover rate will be different at each hospital.

Received 10 December, 2011, Revised 11 January, 2012

Accepted 27 January, 2012

Correspondence: Sunjoo Kim, Department of Laboratory Medicine, Gyeongsang National University School of Medicine, 79 Gangnam-ro, Jinju 660-702, Korea. (Tel) 82-55-750-8239, (Fax) 82-55-762-2696, (E-mail) sjkim8239@hanmail.net
Using 1,000 patient days could be the denominator to compensate for these variables. The authors compared the number of blood cultures by 1,000 patient days for seven university-affiliated hospitals in 2010. The average stay in the hospital ranged from 6.9 to 11.3 days.

The mean number of blood cultures per 1,000 days was $110 \pm 23$ (SD), ranging from 65 to 129 (Table 1). Interestingly, one hospital showed a very low number, 65 , whereas all other hospitals reported more than 100 . In the detailed analysis of blood culture request patterns, this hospital had a much higher proportion (44\%) of cases in which only one set of blood cultures was ordered for adults [6]. The 95\% confidence intervals (CI) of the number of blood cultures per 1,000 patient days were 95 to 125 , which is slightly higher than the data (73-110) from 18 other university-affiliated hospitals in the previous year (data obtained by the authors, but not published). Patients' constitution, disease severity, underlying illness, location of the hospital, and numbers of intensive care units may affect the results. Accordingly, the numbers of blood cultures per 1,000 patient days in this study should not be applied to small hospitals or long-term care facilities. The number (103-188) of blood cultures per 1,000 patient days suggested by Cumitec 1C [5] was higher than ours. The difference between two studies might be secondary to the proportion of patients with acute illnesses or blood culture ordering pattern. Many hospitals had used two sets (about 70\%) for adult patient and one set (about 80\%) for child 
Table 1. Statistics of yearly requested blood culture at 7 university-affiliated hospitals in 2010

\begin{tabular}{|c|c|c|c|c|c|c|c|c|}
\hline & \multicolumn{8}{|c|}{ Hospitals } \\
\hline & A & B & $\mathrm{C}$ & $\mathrm{D}$ & $\mathrm{E}$ & $\mathrm{F}$ & G & Total \\
\hline Blood culture performed (A) & 76,062 & 70,763 & 45,925 & 35,404 & 29,940 & 22,649 & 16,372 & 297,115 \\
\hline Admitted patient numbers (B) & 75,477 & 97,040 & 39,161 & 35,843 & 24,151 & 32,618 & 28,605 & 332,895 \\
\hline Average admission days (C) & 7.8 & 6.9 & 8.8 & 8.37 & 11.3 & 9.7 & 8.8 & 7.9 \\
\hline Total admitted patient days $(\mathrm{B} \times \mathrm{C})$ & 588,718 & 669,571 & 334,619 & 299,985 & 269,823 & 219,695 & 251,726 & $2,634,137$ \\
\hline $\begin{array}{l}\text { Adjusted blood culture by } 1,000 \\
\text { patient days* }(1,000 \times \mathrm{A} / \mathrm{B} \times \mathrm{C})\end{array}$ & 129.2 & 105.7 & 137.2 & 118.0 & 111.0 & 103.1 & 65.0 & 109.9 \\
\hline
\end{tabular}

*Mean, SD, and $95 \%$ confidence intervals are 110,23 , and $95-125$, respectively.

patient in blood culture instead of three sets in the hospitals participated in this study [6].

In conclusion, the mean number of blood cultures per 1,000 patient days was 110 at seven university-affiliated hospitals. The number of blood cultures per 1,000 patient days could be a good parameter to evaluate overuse or underuse of blood culture, but could be affected by blood culture requesting pattern.

\section{ACKNOWLEDGEMENTS}

This research was supported by Basic Science Research Program through the National Research Foundation of Korea (NRF) funded by the Ministry of Education, Science and Technology (2011-0008757).

\section{REFERENCES}

1. Martin GS, Mannino DM, Eaton S, Moss M. The epidemiology of sepsis in the United States from 1979 through 2000. N Engl J Med 2003;348:1546-54

2. McCaig LF, McDonald LC, Cohen AL, Kuehnert MJ. Increasing blood culture use at US hospital emergency department visits, 2001 to 2004. Ann Emerg Med 2007;50:42-8.

3. CLSI. Principles and procedures for blood cultures; approved guideline. CLSI document M47-A. Wayne, PA; Clinical and Laboratory Standards Institute, 2007.

4. Baron EJ, Weinstein MP, Dunne Jr. WM, Yagupsky P, Welch DF, Wilson DM. Cumitech 1C, blood cultures IV. Washington, DC; ASM Press, 2005.

5. Mountain D, Bailey PM, O'Brien D, Jelinek GA. Blood cultures ordered in the adult emergency department are rarely useful. Eur J Emerg Med 2006;13:76-9.

6. Shin JH, Song SA, Kim MN, Lee NY, Kim EC, Kim S, et al. Comprehensive analysis of blood culture performed at nine university hospitals in Korea. Korean J Lab Med 2011;31:101-6. 
=국문초록=

\section{대학병원의 1,000 명 입원환자당 혈액배양 시행 건수}

${ }^{1}$ 서울대학교 의과대학, ${ }^{2}$ 인제대학교 의과대학, ${ }^{3}$ 경상대학교 의과대학, ${ }^{4}$ 성균관대학교 의과대학 삼성서울병원,

${ }^{5}$ 원광대학교 의과대학, ${ }^{6}$ 충남대학교 의과대학, ${ }^{7}$ 계명대학교 의과대학 진단검사의학교실

김의종 ${ }^{1}$, 신정환 $^{2}$, 김선주 $^{3}$, 이남용 ${ }^{4}$, 조지현 $^{5}$, 구선회 $^{6}$, 류남희 $^{7}$, 주세익 ${ }^{1}$

저자들은 2010년 7개 대학병원에서 1,000명 입원환자당 시행한 혈액배양 건수를 조사하였는데, 그 범위는 65-129 (평균 110 )였다. 1,000 명 입원환자당 혈액배양 시행건수는 혈액배양이 적절히 이용되고 있는지 평가하는 도구로 사용될 수 있 을 것이다. [대한임상미생물학회지 2012;15:67-69]

교신저자 : 김선주, 660-702, 진주시 강남로 79

경상대학교 의과대학 진단검사의학교실

Tel: 055-750-8239, Fax: 055-762-2696

E-mail:sjkim8239@hanmail.net 